\title{
Connecting Real and Imaginary Places through Geospatial Technologies: Examples from Set-jetting and Art-oriented Tourism
}

\section{Thierry Joliveau}

Université de Lyon, F-42023 Saint-Etienne, France; CNRS UMR 5600 Environnement-Ville-Société, Université de Saint-Etienne Jean Monnet, F-42023, France

Email: thierry.joliveau@univ-st-etienne.fr

Places play an important role as anchoring fictional (books, movies, songs, video games) as well as artistic universes to reality. Conversely, imaginary places affect the way people perceive real places. 'Set-jetting', which transforms film locations into tourist attractions, is a perfect example of the increasing demand for connecting fictional spaces with real places. The interaction of imaginary and real places, which has been for years an operating function of fiction, is increasing both qualitatively and quantitatively. This is not limited to cinema but also affects literature and art. Once located on a map, the fictional place becomes attractive for tourists and a potential source of profit. The connection between imaginary and real places has been transformed by recent dramatic changes in communication and information technologies, and more specifically in the domain of geospatial technologies. These technologies offer more effective ways of georeferencing locations in films, books and art works. Many Web sites compile information on film shooting locations. Geoparsing techniques offer solutions for automatically georeferencing novels or short stories. New technologies allow visitors practicing set-jetting or cultural tourism to collect extensive information about films or books related to these places. Geospatial technologies contribute to the development of an intermediary territory, a space between the real world and the fantasy world.

Keywords: set-jetting, cinema, art, literature, geospatial technologies, georeferencing

\section{INTRODUCTION}

The interaction between imaginary and real universes has been an operating function of fiction for years, either from the real to the imaginary as in James Barrie's Peter Pan or from the imaginary to the real as in Woody Allen's The Purple Rose of Cairo (1985). On the one hand, places play an important role in this interaction as they anchor fictional universes to reality. On the other hand, places created by writers, painters, film directors or game developers have the ability to transform the way we perceive the world by envisioning new dimensions of representations of reality. The relationship between real and imagined spaces shapes our understanding of geospatial planning activities and practices. The hypothesis is that geospatial technologies will play a major role in the revitalization of this relationship.

The first section of this paper discusses the experience of 'set-jetting' which transforms film locations into tourist attractions. This early cinematic practice (Snickars and Björkin, 2002) was recently reinforced with the release of films such as The Da Vinci Code (Howard, 2006) and the Harry Potter series (Columbus, 2001-2002; Cuarón, 2004; Newell 2005; Yates, 2007). In the second section, the concept of set-jetting is used to better define how the increasing demand for connecting fictional spaces with real places may, in turn, affect the historical realities of the real places. The third section gives an overview of the different theoretical perspectives of the connection between real and fictional spaces. Finally, the fourth section analyses how geospatial technologies have begun to deeply affect these connections at different levels, including the georeferencing of places represented in works of art, the building of databases and the development of interfaces for navigating and requesting information from these applications.

\section{SET-JETTING}

Set-jetting can be considered as a new and rapidly growing form of tourism. Set-jetting involves the visitation of realworld film locations from Hollywood blockbusters by tourists and fans. This practice was popularized recently with the release of The Da Vinci Code. The narrative of the book - and of the film - takes the audience through a series of cultural sites throughout the world (e.g. Paris, Rome, Jerusalem) which, in turn, stimulated the curiosity of the 
public. Many travel agencies foresaw these opportunities and started to organize travel tours called 'Da Vinci Code tours' in which the tourists followed the characters' footsteps and visited the places and monuments that appeared in the film. In the same way, the shooting locations for the series of Harry Potter movies have become a motivation for fans to visit the UK. Hordes of tourists are now visiting Alnwick Castle, where external shots of Poudlard were created, Christ Church on the campus of Oxford University, where the cafeteria scenes were shot, and Gloucester Cathedral, to discover the hallways or Lacock Abbey to visit the classrooms. It is important to emphasize that only the film can generate this kind of tourism. Indeed, the books written by J. K. Rowling never mention any real location apart from the $93 / 4$ platform at King's Cross Station (which now exists between platforms 9 and 10, and tourists have their pictures taken there). The imaginary dimension of these places does not seem to have affected the interest of tourists in visiting them ${ }^{1}$.

This creates a paradox: Hollywood cinema, an industry of artifice, contributes to the 'realization' - the action of making real - of imaginary and fictional places. Obviously, cinema inherently needs to show landscapes and therefore cannot only evoke them as with literature. Even if certain films can bring to life the natural setting of the narrative, most films combine studio shooting with outdoor in situ footage. The few square kilometers of Hogwarts in the Harry Potter series have, in fact, been shot in a dozen natural locations scattered all over England.

This geographical kaleidoscope is inherent to cinema. Amadeus (Milos Forman, 1984), set in Vienna, inspired people to visit Prague where it was actually filmed. The Soviet invasion of Prague in 1968 described in the novel The Unbearable Lightness of Being (Kundera, 1984), was displaced in the eponymous film adaptation (Philip Kaufman, 1988) to Lyon (France), using the same 'natural décor' as the Horloger de Saint-Paul (Bertrand Tavernier, 1974), which actually takes place in Lyon. An ultimate example is the NBC television sitcom Friends created by David Crane and Marta Kauffman. The New York address of the building where this series takes places appears in tourist guides as well as on the Internet, even if almost all of the episodes of this New York-based series were shot in Hollywood. In the series, Joey, one of the six friends, is an actor in the soap opera Days of Our Lives. The real soap opera is shot in Hollywood, not in New York as Friends suggests, and the characters consume a lot of 'Safeway Select' products which are only available in California ${ }^{2}$.

Literature and painting seem to be less confusing in terms of locations as places usually have a great impact on the work of writers and painters. In these artistic disciplines, places create another kind of confusion: confusion between the life of the author and the work. The Dorset where Thomas Hardy lived is - without really being - Wessex, the fictional region that Hardy invented as a background for many of his books. Following multiple tourist guides in Dublin, tourists never really know if they are following the character of Leopold Bloom or the author James Joyce, since both are so intimately intertwined. As literature is less referential as painting or cinema, it provides more freedom to evoke real places, as well as a more subtle form of collage and transformation of these places.

\section{THE REALITY EFFECT OF SET-JETTING}

Through set-jetting, fantasy produces a strong effect on reality. Once located on a map, the fictional place becomes attractive and potential source of real profits. For a long time, cities have been developing strategies in order to attract film crews, which will later attract film tourists (Beeton, 2005). Alnwick Castle (see above) claims 40 years of experience in welcoming cinema and TV crews, and can provide a team of experts in movie making ${ }^{3}$. VisitBritain, the website of the British tourism office, proposes a series of itineraries to discover the different shooting locations all over the $\mathrm{UK}^{4}$. VisitScotland in collaboration with Scottish Screen has produced a promotional video to encourage the 'Da Vinci Code Set-Jetting' in Scotland'.

This market also generates some real economic and political conflicts. The town of Goathland, where the train station was used to shoot the Hogwarts Express in Harry Potter, wanted to develop a marketing strategy around this event, but was denied every right by Warner Bros., the producer of the film, who wanted to keep the rights for the site creation ${ }^{6}$. The town was then denied the right to use the name 'Harry Potter' for its promotion ${ }^{7}$. In a more political domain, the Scottish Deputy Mr P. Wishart of the Scottish National Party attacked the Tourist Authority in 2001 over a promotional brochure that neglected to mention the shooting locations of Harry Potter outside England, despite the Scottish background of J. K. Rowling 8 .

Another more subtle 'effect of the real' is that the real places sometimes begin to look like their fictional representations in painting and cinema. The fictional $93 / 4$ platform at King's Cross has become a reality and Central Perk Bar, which is the key location for the characters in Friends, has been reproduced many times in reality through a franchise called Central Perk. So it is now possible for real people to have a coffee 'Where Friends meet', as the slogan of the franchise suggests. Another interesting example is provided by the caf'e located at 'Place du Forum' in Arles which was painted by Van Gogh in 1888 (Terrasse du café le soir), and was renamed Café Van Gogh in the 1990s. The Café was also repainted in yellow to imitate the unique light effect of the painting. The town of Aracataca, where many of Gabriel Garcia Marquez's short stories and books take place, including the famous One Hundred Years of Solitude, provides another example. In 2006, to stimulate the depressed economy, the mayor of this town proposed renaming the town 'Macondo' - which is the fictional name of the town in the book - in order to ensure that tourists will find it on the map of Colombia, although in the end this was rejected by the townspeople.

Considering how England's landscape was modified in the nineteenth century in order to better fit the aesthetics proposed by the landscape painters of the time, we must consider the impact of the images created by artists on the real landscapes, buildings or sites. The increasing interest to preserve and promote heritage sites and cultural landscapes emphasizes the importance that imaginary places may have on the development and planning of real places and spaces.

In a sense, set-jetting is not really new. It is, in fact, a new avatar of cultural tourism, which is itself an extension of the original form of tourism. Young people from wealthy 
British families used to travel to Europe to visit the historical sites they had discovered in literature. Travellers have always been attracted by the sites described in novels, such as Cabourg's attempts to visualize the 'Balbec d'Albertine' in La Recherche du Temps Perdu, the 'Passage des Panoramas' to discover the 'Paysan de Paris' of Louis Aragon, or the Lands of Haworth expecting to meet the ghost of Heathcliff in Emily Brontë's Wuthering Heights. This goes beyond literature, as sites painted by impressionists have now became major tourist attractions. Landscapes contemplated by tourists are as much artistic and imaginary products as they are real.

Houses of writers and artists, places where they stayed and regions where they were inspired, have become tourist destinations. Tourist offices propose walking tours following the steps of Jane Austen in Bath, of the Brontë sisters in Yorkshire, of Van Gogh in Arles and of Jean Giono in the Drôme. Birgit Plietzsch describes how Hardy's Wessex has now became a marketing concept of the modern tourist industry to attract visitors to Dorset $^{9}$. In his already outdated book on the geography of tourism, Williams talks about the different ways of promoting places that do not exist and gives the example of these imaginary tourist destinations such as the Hardy County, the Shakespeare County and the Robin Hood county (Williams, 1998).

Therefore, set-jetting can be analysed as an indication of the expansion and popularization of earlier practices that made a link between imaginary places generated through artistic practices, and real places. People traveled to see what fictional places looked like, and enriched their perspectives of real places with fictional and idiosyncratic representations provided by artists. This connection between real and imaginary places was, for a long time, only accessible to an elite class. It is now becoming more mainstream with the increasing mobility and the pervasiveness of mass media such as television, cinema and the Internet.

\section{THEORETICAL PERSPECTIVES}

Through visiting different places dedicated to entertainment in France and Europe (Euro Disneyland, Centerparks, Ludwig II's Baviera Castles...), the anthropologist Marc Augé argues that in both urban space and social space in general, the distinction between reality and fiction is becoming increasingly blurred (Augé, 1997). The reality effect of fiction has also been theorized by Jean Baudrillard, whose work is based on the hypothesis of the 'disappearance of the real' (Baudrillard, 1981).

Many geographers have tried to define, understand and explain geographical imaginaries. Gregory (1994) envisioned these as spatial, cultural and historical understandings of places characterizing human groups. Based on Lefebvre (2000) theories, Soja (1996) contributed to this debate. He developed an approach rejecting the traditional dualist views opposing the concrete space of material and physical objects to the mental construction and representation of ideas. Soja argues that the late 1960s saw the emergence of a different way of living and thinking spatially that superceded the opposition between what he calls 'Firstspace' (space of materiality, of the daily life, of the physical processes and social practices) and 'Secondspace' (space of the ideas, representations, signs, texts, images and of the logos which is also the level of discourse, control and surveillance). This 'thirding' way of envisioning space was based on a spatial imaginary, integrating material and mental spaces. Both of these spaces were developed extensively in terms of substance, as well as meaning. According to Soja, the exploration of the 'Thirdplace' involves journeys in what he calls 'real-and-imagined places'. He also uses the cases of Orange County and Los Angeles to demonstrate how, in certain extreme cases, real places are transformed into imaginary ones in a postmodern world. These 'real-and-imagined places' correspond well to the spaces emphasized by set-jetting, which combine characteristics of a real place with the aura created by its artistic and fictional representations.

In art and literary criticism, there are numerous analyses describing the fictional space of the major masterpieces written by authors such as Dickens, Proust, Zola, as well as painters and filmmakers. Nevertheless, there are few attempts to propose a theoretical approach to the overall relationship between a real space of reference and the imaginary space of a creator. Moretti provides one of the best syntheses of the use of the map to study both 'space in literature' and 'literature in space' (Moretti, 2000). The former - which is more directly related to the focus of this paper - can be illustrated through examples such as the analysis of Parisian space in the work of Balzac, or Africa in the colonial novel. By mapping the places where the action of different novels is set (e.g. novels form Austen, Balzac, Dickens, Holmes), Moretti brings to the fore what he calls 'ortgebunden' - 'related to place' - literature: 'what happens depends on the place where it takes place' (Moretti, 2000: 83). This approach shows how this literary genre has its own specific space and how each space possesses its own genre that can be represented by a specific spatial configuration: 'each form has its geography, its borders, its spatial taboos, and its flows of movements' (Moretti, 2000: 11). Historical and colonial novels refer to two different spaces, two different centralities or two different relationships to the border. The mapping of the London used by the characters of the nineteenth century novels reveals a strict separation between two parts - the East and the West - without any links between them. The naturalistic Paris of Emile Zola is characterized by some plots highly dependent on very specific neighborhoods, while the heroes from Balzac navigate all over the city. Moretti demonstrates the interest for literary critics of a fine cartography of novel places - characters, meetings, murders, fights - as well as the importance to model the existing relationships between these places as discussed in his more recent book (Moretti, 2008).

Studying early Swedish documentaries, Snickars and Björkin (2002) argued that any film experience is, to a certain extent, a spatial experience. Tom Conley (2007) generalizes and amplifies the similarities between cinema and cartography through his study of the relationships between maps and films illustrated by a range of different movies from different genres (e.g. film noir, war film, thriller) and directors (e.g. Clair, Renoir, Rosselini, Truffaut, Spielberg) through different places. Conley 
envisions cinema as a 'locational machinery', 'a projective apparatus similar to cartography.' According to this perspective, 'a film can be understood in a broad sense to be "a map" that plots and colonizes the imagination of the public it is said to "invent" and, as a result, to seek to control' (Conley, 2007: 1). Through this metaphorical and conceptual approach, Conley helps to grasp how the film opposes consubstantially the spectator to both the geographical (where am I?), and the ontological (Who am I?) interrogations, which makes film watching a spatial experience par excellence.

In more general terms, arts, semiology and literature studies have provided many analyses on the way fiction address space, and about the role space plays in fiction. Sociologists, historians and geographers have also often explored art and fictions to understand and analyse places and real phenomenon. But these analyses have often only been unidirectional. For instance, according to the current theory in literature, the text is not supposed to represent the real; the text is independent from the real. What is more important is the literary cohesion - its functioning as text as well as its intertextuality - its relationships with other texts. Art and literature often study the space of the narration, but avoid making any reference to real space. For literary critics, the Paris of Balzac must be analysed as a universe by itself and does not require to be linked with the real Paris of the 1830s. On the other hand, when a geographer studies Bordeaux according to Mauriac, Normandie according to Flaubert or New York according to Dos Passos, he tends to use the text as a source of information and to read it as a description of a real place, forgetting sometimes the inherently created dimension of this imaginary space. In the first case, the space of reference dissolves. In the second case, the imaginary space is reduced to a simple reflection of the real space.

The argument of this paper is that we are currently experiencing a connection between imaginary and real spaces, a merging of both instead of the absorption of one by the other. Imagined spaces refer to real spaces - in a more or less direct and allusive way - by remodelling and transforming them. In return, these imagined spaces transform the way we perceive reality. A tourist in New York, Paris or Roma does not see at first a material space. $\mathrm{He}$ arrives with a preconceived view of the reality based on a myriad of cultural, literary and cinematographic references. Based on his culture, his centres of interest and on the nature of the place, these references will vary qualitatively and quantitatively. But there are no places that have not yet been referenced - at least indirectly - by a work of art. What is true for the tourist is even truer for the writer and the filmmaker. It is difficult for a creator to locate a book or to shoot a movie without integrating - consciously or not what has already been written or shot on these specific places. Finally, as was discussed previously, real spaces can be transformed by the imaginary spaces they are connected with.

Therefore, it is necessary to develop an approach that integrates these connections and interactions between real and imaginary spaces without diminishing either of them. This is what Bertrand Westphal (2007) attempts in his geocritical ('géocritique') approach which proposes to reconnect the mimetic arts such as literature, cinema and painting to the real world through the spaces they represent. To do so, Westphal proposes a set of conceptual tools relevant to understanding how human spaces structure themselves 'by and in the text, by and in the image', as well as through the cultural interactions that are created during the process. His approach is geocentred. It positions places - rather than the work of art or the author at the centre of the analysis, by interrelating different representations of the same place. It is interdisciplinary in its objectives as well as in its methods. It combines different tools of analysis taking into account the representations of a specific place through different media (literature or cinema) and different genres (novels or travelogues). The plurality of these representations leads geocritique to describe the multi-sensory nature of space, made up of colors, textures, sounds, smells and material objects. It needs to access to what Westphal calls the 'polycronie' of space, the fact that it is the result of the stratification of natural phenomenon of age, periodicity, and of different temporal speeds. Literary and artistic representations must then be included in the world, in an 'expanded reality', by denying the principle of a distinction a priori between the real and the representational. Therefore, geocritique is integrated with the postmodern approach that acknowledges the contemporary dissolution of the notion of reality, considered as material, unique, determined and common at all. By doing so, Westphal traces a parallel between the 'de-realization' and the explosion of the contemporary city, and the deconstruction of the contemporary narrative, previously pointed out by Soja.

Further discussion on this topic is beyond the scope of this paper, but the geocentric approach proposed by Westphal provides a framework to study at a high level of generalization, the phenomena of connection between imaginary and real spaces, of which set-jetting is only one of the more recent manifestations. By assuming that the analysis of real spaces could be carried out using a similar set of tools and codes as the one used for the imaginary spaces, it allows the analysis and production of a permanent circulation of schemes, shapes and models between reality and fiction. Indeed, the question addressed here is related to the kind of coupling that can be established between places of fiction and real places respecting the logic and the nature of each, and permitting simultaneously the connections and the exchanges between them. The argument is that geospatial technologies will play an important role in these interactions particularly in the current situation where both old and new cultural representations are increasingly becoming digital. These technologies will allow an automatic or a semiautomatic spatial indexation and search of works of art based on location. There has been an eruption in the use of these techniques in art and literature and they have often been associated with an epistemology of pragmatic and material space and of factual and positivist knowledge (Pickles, 1995; Curry, 1998). Even Soja limits these techniques to the 'Firstplace' (Soja, 1996: 76). Their development to build real-and-imagined spaces seems inevitable. Activities like set-jetting are already rapidly expanding and their use reflects major theoretical and methodological changes. 


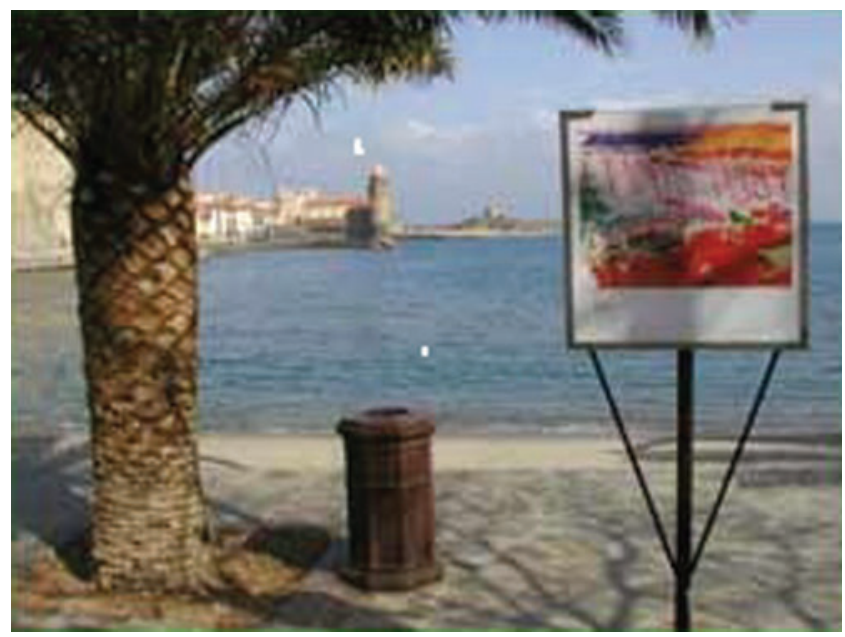

Figure 1. Paintings from the fauvists in Collioures (France)

\section{THE EMERGING ROLE OF GEOSPATIAL TECHNOLOGIES}

Tourism is an activity mostly based on sight, what John Urry (2002) calls 'tourist gaze'. This concept captures the idea that the tourist gaze is directed to features of a landscape or townscape which separate them from everyday experience and denotes a much greater sensibility to visual elements of landscape and townscape that are normally found in everyday life. This importance of the visual explains the central role played by the most diverse spatial representations in tourist activity. The choice of places to be gazed is anticipated, through the creation of diverse forms of materials such as films, books, documentaries and photographs promoting tourist activities. Once on site, tourists capture and produce some new views (e.g. photography, post cards, travelogues), and contribute to their circulation. This tourist gaze is based on the multiple forms of material representations, which are read and interpreted just like signs - in the semiotic sense - usually confirming some mythical preconceptions such as French Romanticism, the Paris of lovers, the Wild West and the Mysterious Orient. Tourism is an extraordinary engine for the circulation of views and signs related to places.

The use of fictional or imaginary representations contributes to this phenomenon. It simultaneously reinforces and spatially defines it. Indeed, fiction contributes to recycle/renew those myths and clichés by making them alive, through their embodiment both by the characters and by the places. Therefore, it is not surprising that modern tourist guides are full of quotes from fiction about places to visit, and artistic and literary representations of these places. Libraries specializing in travel present systematically and in locational proximity maps and guides, novels and essays related to the destinations proposed. It is now commonplace, before or after a trip, to view films set in the places visited. Some specialized books map out film locations (Alleman, 2005a; Alleman, 2005b; Katz, 2005; Hellman et al., 2006; Reeves, 2006; Hellmann and Weber-Hof, 2007). In situ installations are also created. For instance, in Collioure, it is possible to contemplate paintings from the fauvists in locations where they were actually painted ${ }^{10}$ (Figure 1). In Roma, signs describe places where films were

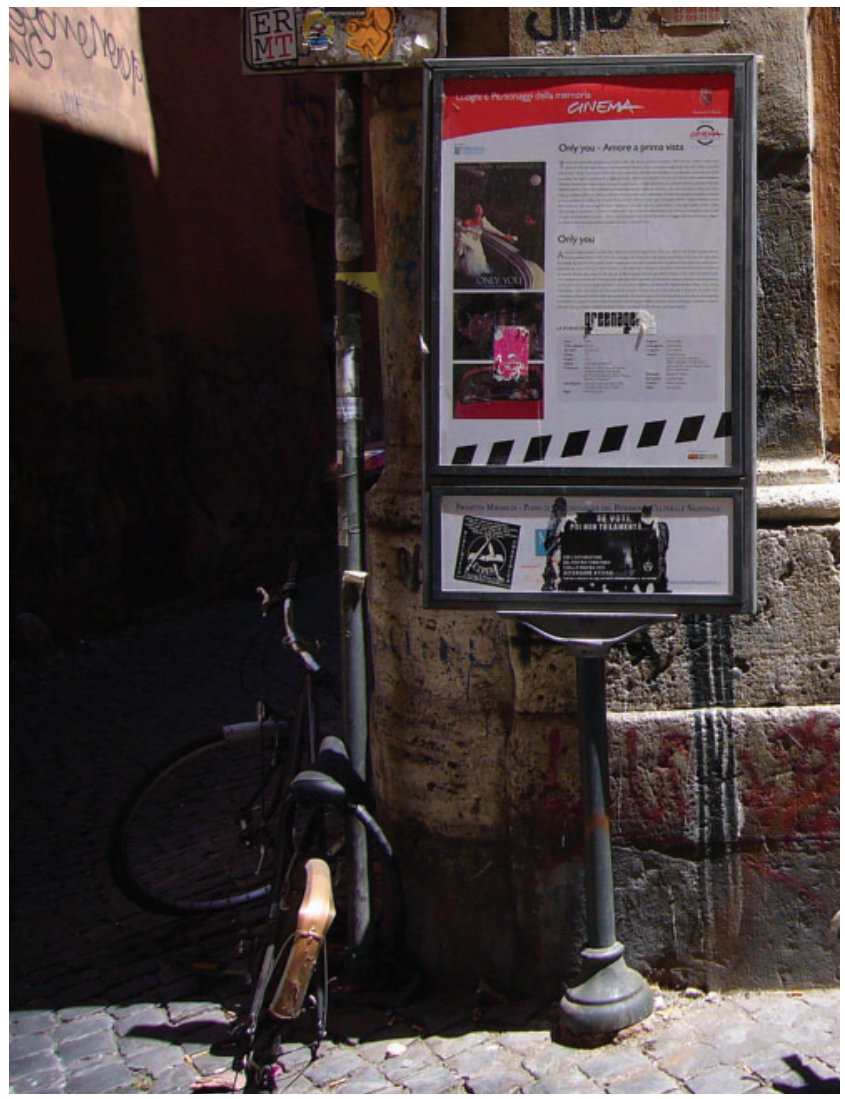

Figure 2. Signs describing film locations in Roma

shot $^{11}$ (Figure 2). A tourist pamphlet synthesizes these shooting spots by neighborhoods ${ }^{12}$. Recent analyses such as the one developed by Hanna and del Casino (2003) show the increasing sophistication of tourist cartography which not only directs tourists to places to see, but also contributes to the creation of chains of representations modifying spaces and local identities, while erasing the difference between the tourist gaze and the everyday life space pointed out by Urry.

Information and communication technologies, and more specifically geospatial technologies, play an increasing role in this circulation of images and signs, contributing to the creation of both, tourist gaze and local identities. These techniques could potentially have a huge impact on the connection between works of art and places. Indeed, they contribute to the convergence, in a common informational space, of artifacts of different kinds and from different sources. They have the potential to create new ways to integrate imaginary universes with the real world. These techniques establish new ways of analysing both real and imaginary spatial worlds. They also raise methodological and technical questions related to spatial analyses related to databases, information retrieval, interface design and visualization of hybrid forms of information. This paper describes some of the changes in analyses of real and imaginary spaces including some which are currently experimental.

\section{Georeferencing works of art}

As outlined by Westphal, the first issue related to a geocritique approach is the diversity of data sources. In 
the institutional databases available on the Internet, works of art are usually organized based on different criteria, such as the publisher's city for books, the museum location for graphic works or the shooting location for movies. It is quite rare to see data structured based on the places they represent and describe. Although locational information is sometimes available, this is usually in documentary form rather than in a database. Georeferencing these data would help to fill this gap. Georeferencing is now applied to a large range of activities. Until recently, it was common to differentiate informal means of referring to locations (e.g. place names), from formal location (e.g. latitude and longitude). Specialists now agree that the best approach is unified georeferencing, in which both formal and informal locations are combined and used in a variety of domains (Hill, 2006).

Georeferencing initiatives are emerging with relative success depending on the discipline. Cinema is the most advanced, as multiple web databases dedicated to movies already exist. For instance, the very popular website Internet Movie Database ${ }^{13}$ provides information on film shooting locations. Other sites are even more specialized, as illustrated by the French site $\mathrm{L} 2 \mathrm{tc}^{14}$ that provides 6200 movie entries, searchable through films, places and geographical synopses. Most of these sites locate films by town or country.

Another perspective is provided by the Movie Location Guide $^{15}$ website. This site presents high resolution topographical images of cities such as New York and Los Angeles. The neighbourhood and street intersection images reflect the shooting locations of specific films. To some extent, all these sites are collaboratively informed. Visitors are invited to propose new film locations. For the moment, only few of these sites propose, in a systematic manner, images of the film illustrating the location, but it seems clear that the tendency is to illustrate more places and spaces (re)presented in the movies.

No such websites were found for paintings or drawings, perhaps because they are much less popular than cinema. However, video games provide a new and interesting platform, rich in terms of imaginary places ${ }^{16}$. Some websites are starting to appear, describing the real places that have inspired video games, but they do not take the form of systematic inventories and databases. Pay-per-access music websites are quite comprehensive, but the sites trying to localize places mentioned in the lyrics are rare and usually developed for quiz purposes only, or they represent personal nostalgic collages from fans, instead of systematic databases. The infrastructure is much more sophisticated in photography in both art and popular practice, as illustrated by very popular location sites such as Flickr $^{17}$ or Panoramio ${ }^{18}$. Even if these sites are mostly used by amateurs and cannot be considered yet as a publication space for famous artworks, some professionals use them as galleries for their own work.

Databases are much less common for literature, but some initiatives are emerging as illustrated by the Literary Atlas of Europe, initiated by a Swiss research team ${ }^{19}$, and by The Atlas of Fiction ${ }^{20}$. This latter example aims to locate masterpieces of mainly British literature such as novels from Jane Austen, Conan Doyle and Charles Dickens.
Localization of fictional places is a tedious process that mobilizes fans, but does not provide systematic and consistent databases. Nevertheless, the georeferencing of texts is easy to generate automatically in comparison to images, either fixed or animated. The process of recognizing spatial references in a text and associating them with geospatial coordinates is called geoparsing. It is a growing domain of research and development. The chief company in the field is MetaCarta ${ }^{21}$, which has developed a program called Gutenkarte ${ }^{22}$ that can automatically georeference major novels. Google also provides Google Books, a mashup $^{23}$ that renders automatically place names from books on a Google map. Each place mark on the Google map shows the quote and the page of the place mentioned in the book. The user can click on it and be redirected to the page of the book, if it is available online. The first book processed was Jules Verne's novel, Around the World in Eighty Days (Figure 3). This technology can be applied to all sorts of books including reports and tourist guides as illustrated by the diversities of the books being mapped on this site: a 1888 guide of New York, a report of the commission on 9/11, War and Peace by Tolstoy and a biography of Bach, among others. This site can be used in multiple ways. One can explore a place based on a guide, develop a systematic analysis of the presence of toponyms in an historical text or visualize the journey of a fictional character as illustrated by Moretti's maps. The number of georeferenced books in Google Books is still small but this is an ongoing process and will grow over time.

In any case, georeferencing requires the existence of one or more contributors. In Google Books, the toponyms analysed are limited to the major cities. The algorithm still has difficulties distinguishing toponyms from other kind of names. For instance, the search for shooting locations in 1000 Famous Locations, a website dedicated to the location of various objects, is limited to one key word that is not necessarily a toponym: Lyon can be associated to the city in France, to Glen Lyon in Pennsylvania or Scotland, to the director Francis D. Lyon, and to 34 actors with the surname Lyon. In the project Gutenkarte, the software systematically mixes people names with toponyms. The geography of 'Le Comte de Monte-Cristo' becomes totally upside down: Spada, a town located in the east of France, becomes a major location of the story, only because of a character named Cardinal Spada.

Many issues still have to be addressed in order to obtain a working tool that could automatically differentiate topohomonyms, people names versus place names, relative locations, changing place names and multi-scalar locations. A fluid navigation between books and maps will require the description of toponyms hierarchically and the development of consistent contributors. It will also require the development of much more powerful analytical tools in terms of semantics and syntax than the ones already created by Google and MetaCarta.

\section{Spatial integration and interrogation}

Georeferencing of spatial objects remains a long and complex process that progresses at various speeds depending on the type of media. The process is faster for cinema, boosted by the collaboration of some motivated Internet users. This 
\begin{tabular}{ll|l} 
Gutenkarte & | map | moovse | catalos \\
Around the World in 80 Days & MetaCarta.
\end{tabular}

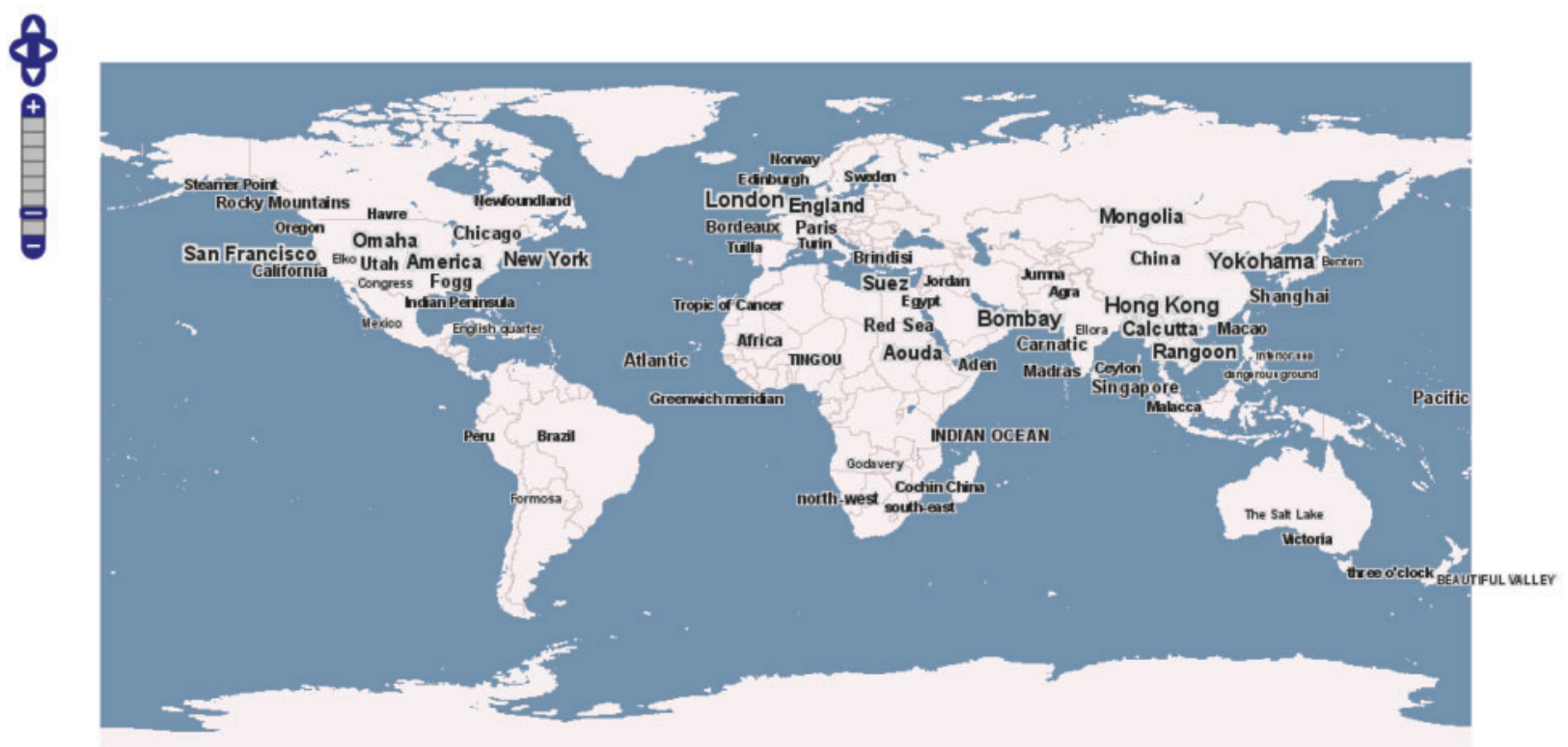

Figure 3. Locations in the Jules Vernes's Novel Around the World in 80 Days

process could be accelerated in the very near future for texts and songs thanks to textual automatic research. However, the process is unlikely to be developed for visual arts.

Another issue concerns the interrelationships of multiple representations of the same place. How can we combine different perspectives of one place? Addressing this issue will require standardization of the spatial descriptions formats, as well as standardization of the user interfaces. Virtual globes have contributed heavily to this standardization. Google Maps is now used in many sites to stock and render spatial information. All kinds of formats (e.g. text, image, video) are now available through virtual globes.

The spatial dimension of a document cannot be reduced to the juxtaposition of place names. As demonstrated by Morretti, it must also integrate elements of polarity, distances, itineraries and points of view. With regard to texts, more complex query solutions than the basic extraction of place names are emerging, as illustrated by the recreation of journeys based on travel diaries (Loustau et al., 2007; Sallaberry et al., 2007). With regard to images, research is in the process of taking into account places where the shot was taken, as well as the overall space described by the image (Joliveau and Rana, 2008). In the same kind of approach, the georeferencing of videos with punctuated place marks is inappropriate to represent journeys, which require more sophisticated descriptive systems.

\section{Visualization and analysis}

If the user interfaces of these systems are simple and intuitive, the query functions remain very basic and the navigation between maps and rich information (photos and text) is still rather awkward. In order to connect real and imaginary places, the navigation between the real sites on the map and the represented space of the fiction must work in both directions. For instance, the navigation in Google Books is incomplete as the toponyms in the books are highlighted but not interactive: the user cannot access the map from the book. Whereas in Gutenkarte, the screen is split: the page of the book is on the left, and the map on the right. The links between the book and the map are active in both directions.

These representations also raise some semiological issues. The slew of pointers provided by Google is very basic and hard to read, but some solutions have recently been developed to present the density of markers ${ }^{24}$. Gutenkarte have developed a more adequate representation by making the font size of the place names proportional to the number of records. More sophisticated forms of visualization are required such as a chronological representation of a journey on the map, with the integration of the page numbers of the book, or the minutes in the film when the specific place appears. An example of such an approach can be found in the Cybercartographic Atlas of Indigenous Perspectives and Knowledge $^{25}$ (Caquard et al., forthcoming).

In general terms, we will have to invent hybrid forms of visualization which are not limited to the juxtaposition of both the imaginary and real ways of expressing space, but which associate and intertwine them as well. This will also require the association of different media such as static images, texts, animated images and maps. Questions related to this hybridizing are not new to geospatial technologies. Atlases are an ancient answer to the association of maps and text. Conley (2007) have demonstrated how cinema developed multiple ways of engaging with cartography. 
Multiple examples from the past can serve as source of inspiration. Nevertheless, a relevant kind of geospatial and multimedia form of writing must be developed in order to represent in an effective way elements of information through the potential of digital cartography. Different domains such as scientific geovisualization (MacEachren, 1995), cybercartography (Taylor,), artistic uses of cartography and GPS must be explored.

An example of the possible use of digital cartography techniques is provided by Moretti who shows that in Les Illusions perdues from Balzac, the reader discovers the city as it unfolds through the steps of Lucien de Rubempré. He opposes this linear spatial and continuous structure, to the discrete one - and in 'flee jumps' - used by Dickens in Our Mutual Friend. But Moretti's maps - which are not always clear and somehow outdated - do not really convey these opposing structures. Animated maps might better represent this phenomenon. In general terms, geovizualisation and cybercartography provide appropriate ways of representing temporal changes in fiction. Metaphorical constructions are also possible. Could we assimilate the spatial description of Balzac with a GPS trace, while the one from Our Mutual Friend with a more cadastral form of topography? A second example is the rendering of impossible topographies from cinema which brings together certain distant real places to invent new topologies, and which might be mapped using anamorphosis. In the context of this paper, it is impossible to provide a complete inventory of the potential forms of visualization available for two reasons. First, because the representation of text or image with maps has always generated complex issues related to information overload. This will become even truer as the screens of personal devices available for tourist applications become even smaller. Furthermore, connecting places of fiction visually with real places raises a number of specific issues related to the complex issues of topographies and topologies. Second, the fast improvement and simplification of geovisualization techniques such as the visualization of cities in three-dimension, opens new perspectives to integrate movies. German artists Joachim Sauter and Dirk Lüsebrink propose to embed films as voluminous objects in three-dimensional "maquettes" 26 . There is a lot of room for innovations in this domain, but we need to focus on improving the connection between researches in scientific geovisualization and artistic experimentations.

\section{Exploring devices}

Traditional audio tours have moved beyond the museum and are now available outdoors through CDs which offer better flexibility to tourists to enjoy their tours at their own convenience (e.g. Soundwalk ${ }^{27}$ ). But the future will surely be based on geo-services. This new practice provides rapid and precise information to users pertaining to location and the services within the area. The current versions remain mainly utilitarian: Where am I? How can I get there? Where are the nearest restaurants? Nevertheless, they are moving toward a spatial representation of social networks (see the analysis of van Weelden, 2006). But tourists and visitors practicing setjetting are an interesting target that could benefit from information about films related to places where they are, where they have been and where they are going. They could access shooting locations as well as visualize the landscapes as they appear in the fiction. A simple car radio synchronized with a GPS can be used to provide relevant commentaries, and appropriate quotes from novels, based on the places and landscapes visited (e.g. tourism radio in Cape Town ${ }^{28}$ ).

Images and movies will soon appear on the screens of embedded GPS units. Samsung already markets a digital camera that can be used as a futurist audio guide as soon as it integrates a GPS unit $^{29}$. In spite of their small screens, mobile phones are as well adapted to this kind of service as they are pervasive. Manufacturers like Nokia are already developing such technologies ${ }^{30}$. PDA is another interesting device for this purpose as it is a multimedia and interactive unit, capable of integrating pointing functionalities such as the one introduced by I-spatialtech ${ }^{31}$, which allows visitors to get information on a building by orienting the device in the direction of the building; this is already common in museums. Finally, in the long term, augmented and virtual reality devices that are developing rapidly could be used to improve the sense of immersion into universes that will intimately combine real and imaginary places.

Static devices should not be ignored. The graphic design quality of mobile technologies might remain low for some times, reducing the quality of the overall experience. On desktops, virtual worlds such as Second Life could then be still relevant and useful in exploring virtual universes mixing real and imaginary. As argued by Dewailly (1999), sustainable development should lead to the merging of virtual and real tourism, rather than seeing them as opposing approaches.

\section{CONCLUSION: TOWARD NEW PRACTICES?}

The instantaneous connection between books, visual art, music, movies and real places is now technologically feasible through the web and in situ through mobile technologies. These new interfaces provide the visitor with an opportunity to create richer environments in which he could become the true actor in a fictional universe 'made real'. In some prototypes of online games (e.g. Massively Multiplayers Online Role Playing Games), the world of the video game incorporates elements of reality. With their cellular phones on hand, players move in the real world while constructing virtual buildings, creating virtual traps and avoiding virtual ambushes. Similar devices could be used to reproduce lost sites from fictional films or to compare historical images to current aspects of buildings, and to futuristic three-dimensional models. It will become possible to follow lost characters from a science fiction movie in a contemporary city. It could even be possible to mix different types of representations, including characters from novels, with paintings and musical ambiances.

This does not mean that the only goal of imaginary places is to be projected on real places. Devices could be used to explore autonomous imaginary places, or to disconnect imaginary places from the reality. In some way, one proof of the 'existence' of Treasure Island in the Pirates of the Caribbean movies (Gore Verbinski, 2003-2006-2007) is that it is possible to visit it on Google Earth ${ }^{32}$. Tour operators offering tours of virtual world such as Second 
Life, or of virtual games such as World of Warcraft or Guild Wars $^{33}$, are also emerging. Bridges already exist between the imaginary and virtual world. At the end of 2007, the forensic scientists of the Crime Scene Investigation: New York television show extended their investigations into the world of Second Life ${ }^{34}$. The fans of the show were invited to create avatars and solve crimes of their own in this virtual world. These devices will provide some new opportunities to creators, as illustrated by the extensive use of Google Maps by Charles Cummings to write his new story 21 Steps $^{28}$. We can imagine that new writers will continue to create stories connecting different fictional universes and artistic disciplines.

The disparate forms this connection will take remain to be seen. One possible development could be through Web 2.0. Dedicated individuals and fans will contribute on a voluntary basis to the connection between imaginary and real spaces that are of interest to them. Websites of shooting locations are already depending on users contributions. The heroes of the realistic TV show 24 can now be followed through collaborative web maps ${ }^{35}$. Nevertheless, most of the applications will probably be commercial. Issues related to copyright will require access to money from commercial advertising, the cities and regions involved, local tour operators, set-jetting agencies, book publishers, on demand video services and telecommunication operators. It is becoming clear that a business model surrounding setjetting is struggling to emerge, based on advertising tourist destinations related to shooting locations.

Geospatial technologies will contribute to the development of an intermediary territory, a space between the real world and the fantasy world. This information space drifts between the real and the fantastic, which links and transforms each of these spaces. This can be considered positively or negatively. On the positive side, we can celebrate this enriching integration of imaginary into the real, as well as the cultural possibilities provided by new forms of tourism. On the negative side, we might regret the loss of imaginary stimulation associated with the necessity of using technological devices to explicitly represent relationships that might otherwise have remained subtle. In the end, what is important to understand is that all of this is already happening with technologies that are already widely available, and that could hopefully be used in a creative way.

\section{BIOGRAPHICAL NOTES}

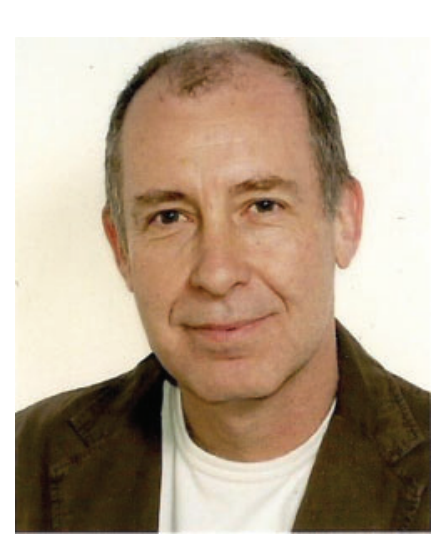

Thierry Joliveau is Professor of Geography and Geomatics at Jean Monnet University of Saint-Etienne (France) where he is in charge of the Master "GIS and Space Management". He is member or the CNRS research laboratory EVS (Environnement, Ville, Société). His research interests include several topics relating to the use of Geographical Information in environmental management and landscape planning. He is presently director of the French national network MAGIS (Models and Applications of Geographical Information Science) that groups together 32 French research laboratories and institutions in GIS.

\section{ACKNOWLEDGEMENTS}

The author thanks the reviewers for their very simulating remarks about the first version of this paper. Their propositions strongly contribute to the ideas proposed in the ultimate version. He would also like to thank Sébastien Caquard and D. R. Fraser Taylor for their important contribution to the translation and editing of the English version of this text.

\section{NOTES}

${ }^{1}$ http://www.encyclopedie-hp.org/essays/essay-londonlocations.php

2 http://www.imdb.com/title/tt0108778/goofs

3 http://www.alnwickcastle.com/location.php

4 http://www.visitbritain.fr/things-to-see-and-do/interests/films-and-movies/index.aspx

5 http://news.bbc.co.uk/2/hi/uk_news/scotland/ 4885342.stm

${ }^{6}$ http://www.glendalehouse.co.uk/pages/harrypotter.htm

7 http://www.besteducationnetwork.org/documents/ ttvi/pdf/Sue\%20Beeton.pdf

${ }^{8}$ http://www.elmundo.es/elmundo/2006/06/26/cultura/1151307386.html and http://findarticles.com/p/ articles/mi_qn4156/is_20021110/ai_n12580010

9 http://www.st-andrews.ac.uk/ bpl0/wessex/

10 http://www.collioure.net/fenetre.asp

11 http://www.romeguide.it/romailgrandeset/romailgrandeset.htm\#top

12 http://www.romaturismo.it/v2/richiestamateriali/ pdf/cinema_en.pdf

13 http://us.imdb.com/

14 http://www.12tc.com/index.php

15 http://www.movielocationsguide.com/

16 http://theboweryboys.blogspot.com/2008/04/his-

tory-of-new-york-city-in-video-games.html

17 http://www.flickr.com/

18 http://www.panoramio.com/

19 http://www.literaturatlas.eu/

20 http://www.atlasoffiction.com/

21 http://www.metacarta.com/

22 http://gutenkarte.org/map/1184

23 http://booksearch.blogspot.com/2007/01/booksmapped.html

24 http://www.mapeed.com/

25 http://atlases.gcrc.carleton.ca/glsl/treaties/season l_ legl.xml.html\#seasonl_legl

26 http://www.artcom.de/

index.php?option $=$ com_acprojects \&page $=6 \&$ id $=26 \&$ Ite$\mathrm{mid}=144 \&$ details $=0$ \&lang $=\mathrm{en}$

27 http://www.soundwalk.com/tours.php

28 http://www.tourismradio.co.za/ 
29 http://www.youtube.com/

watch? $\mathrm{v}=1 \mathrm{X} 9$ tEysGbqM\&mode $=$ related\&search $=$

30 http://www.technologyreview.com/Infotech/18291/

$? \mathrm{a}=\mathrm{f}$

31 http://www.i-spatialtech.com/

32 http://www.discoverpirateisland.com/

33 http://www.synthravels.com/visitors/?lang=en

34 http://kotaku.com/gaming/virtual-worlds/csi-sec-

ond-life-312328.php

35 http://www.wayfaring.com/maps/show/4698

\section{REFERENCES}

Alleman, R. (2005a). Hollywood: The Movie Lover's Guide: The Ultimate Insider Tour of Movie L. A., Bantam Dell Pub Group, New York.

Alleman, R. (2005b). New York: The Movie Lover's Guide: The Ultimate Insider Tour of Movie New York, Bantam Dell Pub Group, New York.

Augé, M. (1997). L'Impossible Voyage. Le Tourisme et ses Images, Rivages, Poche.

Baudrillard J. (1981). Simulacres et Simulations, Galilée, Paris

Beeton, S. (2005). Film-induced Tourism, Multilingual Matters Limited, Clevedon.

Caquard, S., Pyne, S., Igloliorte, H., Mierins, K., Hayes, A. and Taylor, D. R. F. (Forthcoming, accepted Oct. 6, 2008). "Living' Atlas for Geospatical Storytelling: The Cybercartographic Atlas of Indigenous Perspectives and Knowledge of the Great Lakes Region', Cartographica.

Conley, T. (2007). Cartographic Cinema, University of Minnesota Press, Minneapolis, MN

Curry, M. R. (1998). Digital Places: Living with Geographic Information Technologies, Routledge, London.

Dewailly, J.-M. (1999). 'Sustainable Tourist Space: From Reality to Virtual Reality?', Tourism Geographies, 1, pp. 41-55

Gregory, D. (1994). Geographical Imaginations, Blackwell, Cambridge, MA and Oxford.

Hanna, S. P. and del Casino, V. J. (Eds.). (2003). Mapping Tourism, University of Minnesota Press, Minneapolis, MN.

Hellman, C., Weber-Hof, C. and Merzeder, G. (2006). On Location: Cities of the World in Film, Bucher, München.

Hellmann, C. and Weber-Hof, C. (2007). On Location 2: Famous Landscapes in Film, Bucher, München.

Hill, L. (2006). Georeferencing. The Geographic Associations of Information, MIT Press, Boston, MA.
Joliveau, T. and Rana, S. (2008). 'Using urban viewsheds for embedding geographical context in photograph databases of urban areas', in GISRUK Conference, Manchester, UK, Apr 2-4, pp. 223-225. http://www.unigis.org/gisruk_2008/proceedings/joliveau_rana.pdf

Katz, C. (2005). Manhattan on Film: Walking Tours of Hollywood's Fabled Front Lot, Limelight Editions, New York.

Lefebvre, H. (2000). La Production de l'Espace, 4th ed., Anthropos, Paris.

Loustau, P., Gaio, M. and Nodednot, T. (2007). 'Des déplacements à l'itinéraire, du syntagme au discours. Extraction d'itinéraires d'un corpus de récits de voyages', in SAGEO 2007, Rencontres Internationales Géomatique et Territoire, Saint-Etienne, Jun 21 and 22, http://www.emse.fr/site/SAGEO2007/CDROM/ p36.pdf (accessed 29th April 2008).

MacEachren, A. M. (1995). How Maps Work: Representation, Visualisation and Design, Guilford Press, New York and London.

Moretti, F. (2000). Atlas du Roman Européen, Editions du Seuil, Paris (édition originale italienne: 1997).

Moretti, F. (2008). Graphes, Cartes et Arbres. Modèles Abstraits Pour une Autre Histoire de la Littérature, Les Prairies Ordinaries, Paris (edition originale en anglais: 2005).

Pickles J. (Ed.). (1995). Ground Truth. The Social Implications of Geographic Information Systems, Guilford Press, New York.

Reeves, T. (2006). The Worldwide Guide to Movie Locations, new updated ed., Titan Books, London.

Sallaberry, C., Gaio, M., Loustau, P. and Lesbegueries, J. (2007). 'A semantic approach for geospatial information extraction from unstructured documents', in How Geobrowsers, Social Software and the Web 2.0 are Shaping the Network Society, ed. by Scharl, A. and Tochtermann, K., pp. 93-105, Springer, London.

Snickars, P. and Björkin, M. (2002). 'Early Swedish (non-fiction) cinema and cartography', Historic Journal of Film, Radio and Television, 22, pp. 275-290.

Soja, E. W. (1996). Thirdspace: journeys to Los Angeles and other real-and-imagined places, Oxford, Blackwell, Malden (Mass.).

Taylar, D. R. F. (2003). 'The Concept of Cybercartography', in Maps and the Internet, ed. by Peterson, M. P., pp. 405-420, Elsevier, Amsterdam.

Urry, J. (2002). The Tourist Gaze, Sage Publications Ltd, London. van Weelden, D. (2006). 'Possible worlds', in Else/Where: Mapping New Cartographies of Networks and Territories, ed. by Abrams, J. and Hall, P., pp. 26-29, University of Minnesota Press, Minneapolis, $\mathrm{MN}$.

Westphal, B. (2007). La Géocritique. Réel, Fiction, Espace, Les Editions de Minuit, Paris.

Williams, S. (1998). Tourism Geography, Routledge, London. 